\section{(6) OPEN ACCESS}

\title{
OCT angiography in the management of choroidal neovascular membrane secondary to Sorsby fundus dystrophy
}

\author{
Aditi Mohla, ${ }^{1}$ Kamron Khan, ${ }^{1,2}$ Melissa Kasilian, ${ }^{1,2}$ Michel Michaelides ${ }^{1,2}$
}

${ }^{1}$ Moorfields Eye Hospital NHS Foundation Trust, London, UK ${ }^{2} U C L$ Institute of Ophthalmology, London, UK

\section{Correspondence to} Professor Michel Michaelides, michel.michaelides@ucl.ac.uk

Accepted 13 August 2016
CrossMark

To cite: Mohla A, Khan K, Kasilian $\mathrm{M}$, et al. BMJ Case Rep Published online: [please include Day Month Year] doi:10.1136/bcr-2016216453

\section{SUMMARY}

We describe the management of a woman aged 52 years with molecularly confirmed Sorsby fundus dystrophy, who presented with acute visual deterioration in her right eye. Fundus examination identified a right macular lesion suggestive of a choroidal neovascular membrane (CNVM). Optical coherence tomography angiography (OCTA) confirmed the presence of a CNVM. She was treated with 2 monthly intravitreal injections of bevacizumab, associated with OCTA evidence of regression of the CNVM and improvement in her visual acuity. OCTA is a novel, non-invasive method of imaging the retinal vasculature. Images are acquired rapidly, with no associated side effects, offering advantages over the current gold standard technique-fundus fluorescein angiography.

\section{BACKGROUND}

To date, the use of optical coherence tomography angiography (OCTA) has been reported in association with several forms of retinopathy but thus far not in inherited retinal disease (IRD). ${ }^{1-7}$ Sorsby fundus dystrophy (SFD) is an autosomal dominant retinopathy characterised by nyctalopia, commonly in the fourth to fifth decade, followed shortly thereafter by the loss of central vision as a result of macular atrophy or choroidal neovascularisation. ${ }^{8-11}$ Earlier, there was no effective treatment for choroidal neovascular membrane (CNVM). ${ }^{12-14}$ Since the availability of antivascular endothelial-derived growth factors (VEGF) that may be administered directly into the vitreous, outcomes have significantly improved. ${ }^{15}$

\section{CASE PRESENTATION}

A woman aged 52 years, known to have molecularly confirmed SFD (TIMP3 p.Arg204Cys), presented to the eye clinic with a 3-month history of reduced vision in the right eye (figure 1 depicts the fundus appearance of SFD). Her acuity had fallen from $6 / 9$ to $6 / 60$ in this eye and funduscopy revealed a macular lesion suggestive of a CNVM (figure 2). The left eye had good vision (6/9) and no evidence of neovascularisation.

\section{INVESTIGATIONS}

OCT imaging identified hyper-reflective material in the subretinal space which was associated with subretinal and intraretinal fluid (figure 2). This material was presumed to represent a complex of neovascular tissue; however, the resolution was not sufficient to directly visualise the retinal vasculature. OCTA imaging was then performed, identifying an abnormal vascular network arising from the choroid and invading the subretinal space (CNVM).

\section{DIFFERENTIAL DIAGNOSIS}

A differential diagnosis for CNVM is age-related macular degeneration (AMD). However, our patient had molecularly confirmed SFD. She had clinical signs for the same and CNVM is a known complication of this retinal condition. She is also of a younger age group compared with patients with CNVM secondary to AMD.

\section{TREATMENT}

After obtaining informed consent and approval of NHS funding, our patient was treated with two intravitreal bevacizumab injections, 4 weeks apart.

\section{OUTCOME AND FOLLOW-UP}

Treatment was associated with a symptomatic improvement in vision $(6 / 60$ to $6 / 18)$. OCT biomarkers of activity also improved as the fluid seen on OCT imaging was seen to resolve (figure 2). Direct CNVM regression was visible using OCTA (figure 3). Our patient will now be monitored to ensure that the CNVM remains inactive.

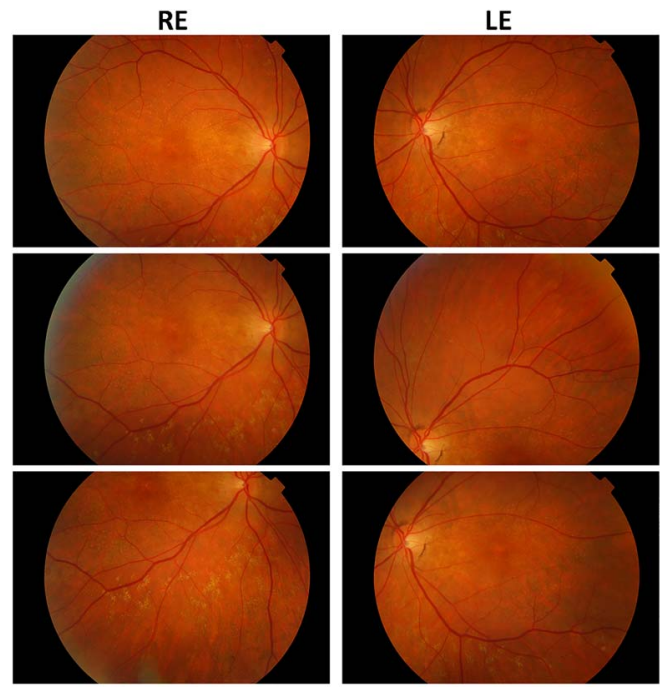

Figure 1 Fundus photos of Sorsby fundus dystrophy (prechoroidal neovascular membrane). 

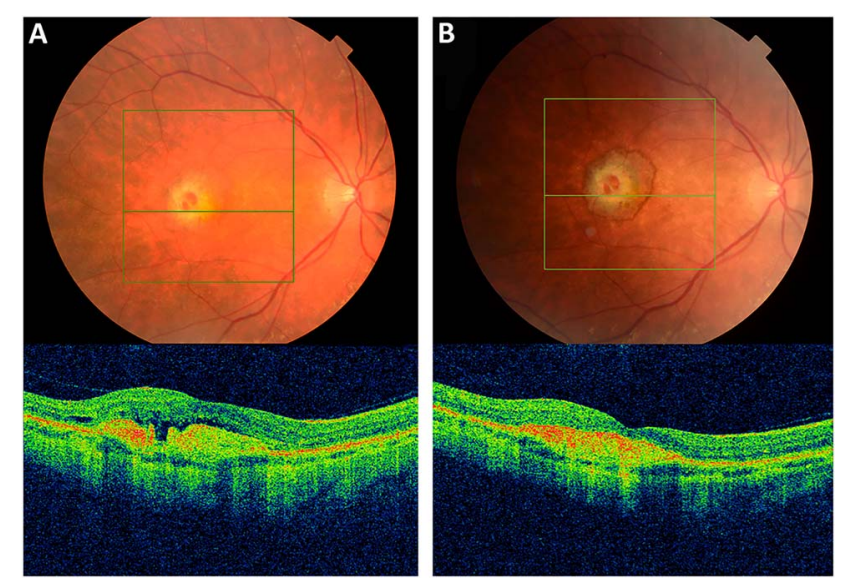

Figure 2 (A) Fundus photo and corresponding optical coherence tomography scan of right eye choroidal neovascular membrane secondary to Sorsby fundus dystrophy (Pre-treatment).

(B) Corresponding images post Intravitreal Bevacizumab \#1.
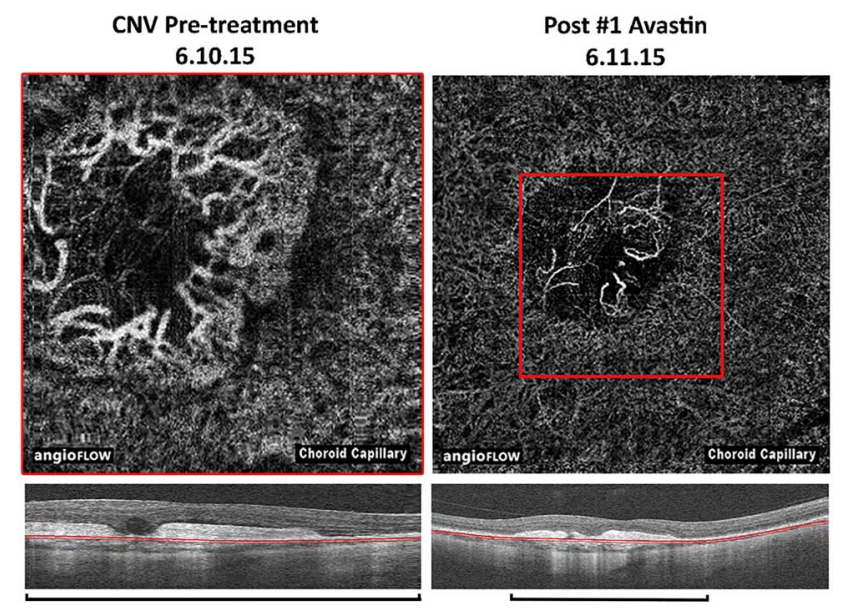

Figure 3 Optical coherence tomography (OCT) angiography images of the choroidal neovascular membrane pretreatment and postbevacizumab treatment, with comparison on OCT (automated segmentation, note the magnification bars).

\section{DISCUSSION}

The speciality of ophthalmology is one of the greatest single users of imaging in medicine. OCTA is the latest iteration of OCT, a technique that has revolutionised ophthalmic imaging, and thereby patient care, over the past decade. This report highlights the utility of OCTA in patients with IRD, the most common form of blindness in the working age population in England and Wales. ${ }^{16}$ As the current 'gold standard' method for detecting CNVM (fundus fluorescein angiography, FFA) is invasive, time-consuming, costly and associated with a mortality rate of $\sim 1: 222000$ and other less severe allergic reactions, OCTA offers significant advantages to patients. The high acceptance rate will enable patients to be imaged at frequent intervals, previously impossible with FFA. It offers the opportunity to improve understanding of CNVM formation and regression in IRD and other forms of retinal disease (including wet AMDleading cause of visual loss in the elderly population). It also provides potentially better directed treatments based on directly imaging the vascular networks that anti-VEGF therapy aims to target.

\section{Patient's perspective}

- In September 2015, I went to my opticians as I was struggling to see at work. Photos were taken of my eyes and the optician said she was not happy about the back of the right eye, she thought it looked like a hole. As she was aware of my condition (Sorsby's dystrophy) and that I was under Moorfields Eye Hospital, she advised me to send copies to my consultant, which I did and managed to get an appointment in 3 days time.

- When I was seen at Moorfields by Dr A. She informed me that there was fluid leaking at the back of my eye. We discussed what could stop it and she advised that an Avastin injection into the eye could hopefully stop the leakage. All side effects were listed, but I decided to have it performed. Dr A told me that a needle had to go into the eye and the vision could be blurred for a while. I was apprehensive about it but went ahead. The needle going in felt like a bee sting/needle prick. I can then remember the fluid looking like bubbles floating around the eye, which was very weird. Afterwards, it did feel painful, which was expected, but not unpleasant. For a few days after it was quite sore, but when you think, a needle had gone straight into the eye, it was not surprising. Dr A advised me that I would probably need 3 injections a month apart and I was to return the next month.

- For the second injection, I was more nervous as I knew what to expect, the bubbles took longer to go this time. I had various scans and I was shown how the injections were helping but I might need another one.

- When I returned a month later, again I had further scans, I was then told that the fluid had stopped leaking and I would not need a third. I was told initially that the fluid in the injections would hopefully repair/stop the fluid from leaking, but in doing so could lead to scarring and could affect my vision. Having seen the retinal images, I could see the before and after and was amazed at the difference. $\operatorname{Dr}$ A explained the difference of the images and what the injections had achieved.

- I cannot praise Moorfields enough, you are always treated with respect, and they explain what is going on and why all the scans are taken.

- I attended the clinic in March 2016 for a follow-up appointment and was told there was no further fluid leaking, but along with my condition of Sorsby's dystrophy and the Avastin injections, the scarring had affected my central vision and I could no longer see the letters on the eye chart.

\section{Learning points}

- Sorsby fundus dystrophy (SFD) is a cause of premature macular degeneration and is transmitted in an autosomal dominant manner.

- Optical coherence tomography angiography is a novel technique useful for visualising choroidal neovascular membrane (CNVM) and monitoring response to treatment.

- It is a safe, non-invasive and quick method as opposed to conventional fundus fluorescein angiography and the images are easily comprehensible to patients-which will revolutionise the way retinovascular diseases are managed.

- CNVM secondary to SFD responds well to antivascular endothelial-derived growth factors therapy. 
Competing interests None declared.

\section{Patient consent Obtained.}

Provenance and peer review Not commissioned; externally peer reviewed.

Open Access This is an Open Access article distributed in accordance with the Creative Commons Attribution Non Commercial (CC BY-NC 4.0) license, which permits others to distribute, remix, adapt, build upon this work non-commercially, and license their derivative works on different terms, provided the original work is properly cited and the use is non-commercial. See: http://creativecommons.org/ licenses/by-nc/4.0/

\section{REFERENCES}

1 Dansingani KK, Naysan J, Freund KB. En face OCT angiography demonstrates flow in early type 3 neovascularization (retinal angiomatous proliferation). Eye (Lond) 2015;29:703-6.

2 De Carlo TE, Bonini Filho MA, Chin AT, et al. Spectral-domain optical coherence tomography angiography of choroidal neovascularization. Ophthalmology 2015;122:1228-38.

3 Ishibazawa A, Nagaoka T, Takahashi A, et al. Optical coherence tomography angiography in diabetic retinopathy: a prospective pilot study. Am J Ophthalmol 2015;160:35-44.e1.

4 Jia Y, Bailey ST, Hwang TS, et al. Quantitative optical coherence tomography angiography of vascular abnormalities in the living human eye. Proc Natl Acad Sci USA 2015; 112:E2395-402.

5 Spaide RF. Optical coherence tomography angiography signs of vascular abnormalization with antiangiogenic therapy for choroidal neovascularization. Am J Ophthalmol 2015;160:6-16.
6 Spaide RF, Klancnik JM Jr, Cooney MJ. Retinal vascular layers in macular telangiectasia type 2 imaged by optical coherence tomographic angiography. JAMA Ophthalmol 2015;133:66-73.

7 Spaide RF, Klancnik JM Jr, Cooney MJ. Retinal vascular layers imaged by fluorescein angiography and optical coherence tomography angiography. JAMA Ophthalmol 2015; 133:45-50.

8 Sorsby A, Mason MEJ, Gardner N. A fundus dystrophy with unusual features (late onset and dominant inheritance of a central retinal lesion showing oedema, haemorrhage and exudates developing into generalized choroidal atrophy with massive pigment proliferation). Br J Ophthalmol 1949;33:67-97.

9 Weber BHF, Vogt G, Pruett RC, et al. Mutations in the tissue inhibitor metalloproteinases-3 (TIMP3) in patients with Sorsby's fundus dystrophy. Nat Genet 1994:8:352-6.

10 Polkinghorne PJ, Capon MRC, Berninger T, et al. Sorsby's fundus dystrophy: a clinical study. Ophthalmology 1989:96:1763-8.

11 Hoskin A, Sehmi K, Bird AC. Sorsby's pseudoinflammatory macular dystrophy. Br J Ophthal 1981;65:859-65.

12 Atan D, Gregory Evans CY, Louis D, et al. Sorsby fundus dystrophy presenting with choroidal neovascularisation showing good response to steroid treatment. Br J Ophthalmol 2004;88:440-1.

13 Holz FG, Haimovici R, Wagner DG, et al. Recurrent choroidal neovascularization after laser photocoagulation in Sorsby's fundus dystrophy. Retina (Philadelphia, Pa) 1994;14:329-34.

14 Sivaprasad S, Webster A, Egan C, et al. Clinical course and treatment outcomes of sorsby fundus dystrophy. Am J Ophthalmol 2008;146:228-34.e2.

15 Prager F, Michels S, Geitzenauer W, et al. Choroidal neovascularization secondary to Sorsby fundus dystrophy treated with systemic bevacizumab (Avastin®). Acta Ophthalmol 2007;85:904-6.

16 Liew G, Michaelides M, Bunce C. A comparison of the causes of blindness certifications in England and Wales in working age adults (16-64 years), 1999-2000 with 2009-2010. BMJ Open 2014;4:e004015.

Copyright 2016 BMJ Publishing Group. All rights reserved. For permission to reuse any of this content visit

http://group.bmj.com/group/rights-licensing/permissions.

BMJ Case Report Fellows may re-use this article for personal use and teaching without any further permission.

Become a Fellow of BMJ Case Reports today and you can:

- Submit as many cases as you like

- Enjoy fast sympathetic peer review and rapid publication of accepted articles

- Access all the published articles

- Re-use any of the published material for personal use and teaching without further permission

For information on Institutional Fellowships contact consortiasales@bmjgroup.com

Visit casereports.bmj.com for more articles like this and to become a Fellow 